Canadian University Music Review

Revue de musique des universités canadiennes

\title{
"Against Punk, New Wave, Avantgarde \& Minimalist Composers"
}

\section{Stepchild}

Numéro 5, 1984

URI : https://id.erudit.org/iderudit/1013935ar

DOI : https://doi.org/10.7202/1013935ar

Aller au sommaire du numéro

Éditeur(s)

Canadian University Music Society / Société de musique des universités canadiennes

ISSN

0710-0353 (imprimé)

2291-2436 (numérique)

Découvrir la revue

Citer ce document

Stepchild (1984). "Against Punk, New Wave, Avantgarde \& Minimalist Composers". Canadian University Music Review / Revue de musique des universités canadiennes, (5), 136-138. https://doi.org/10.7202/1013935ar

All Rights Reserved @ Canadian University Music Society / Société de musique des universités canadiennes, 1984
Ce document est protégé par la loi sur le droit d'auteur. L'utilisation des services d’Érudit (y compris la reproduction) est assujettie à sa politique d'utilisation que vous pouvez consulter en ligne.

https://apropos.erudit.org/fr/usagers/politique-dutilisation/ 


\section{Against Punk, New Wave, Avantgarde \& Minimalist Composers}

Licking labels

like "ambient fourth world music"

Hearing sounds

the final appropriations

of all the men who have blown each other

down all the tubes of creation

molimo of millenia

dijerido of the dead and down

Mocked out

Mechanized

Made ambient airport art

for recreation of celebrities

It excites the white boy mind

more than Jack Barth or Frank Zappa

to create a whole hip tribe on tape

Aboriginals of third world die

Originality of first world individuals

make heap big fourth world

beyond 1st, 2nd, 3rd,

and all mere labels

Filtered winds

Recycled ululations

Snipped vocal cords

Bottom beats stolen from battered Burundi

by punk posers and Composers

aware of the administrative massacres

so sensitive to suffering

They die and die and die some more

While corporations have their way

No need to name the Nambikwara or any other people fading fast

We have the myths, the dream theories the songs on LP records 
Any creative Artist

with 16 tracks of tape

and the appropriate technology

can replace the people

amendment by total substitution

Make water

Add insects and peeper frogs

(digital and analog)

Modulate mouth piece

Dissect dead birds

Grab gamelan and bits of Afro-xylophone

Above all

blow down the tubes

Fallopian frustration

tuned test tubes cracking pan pipes

turning world's last tendernesses

into echocatastrophe

From clock springs

Hacksaw blades

Bobby pins

Nails

Agidigbo!

Kalimba!

Mbira!

Old and new names

for sounds from scrap

Do agidigbo and piri

Do the do stay put in you

Accept no substitootings

no substasquatings

no dub rastafartings

Do agidigbo till fingers bleed

or the steel is softened

Certain that thickened skin is skin not the enfolded skin of calloused mind

Hold on to names

of all the plants and pipes and peoples

All the softness is still ours

All the gentleness of small sounds chipmunks in fall leaves

clay flake wind chimes

mosses growing

snaildarter darting

Every motion has its sound

every sound its emotion 
Every animal one track all its own and not 16

Without lamps

We spend more time awake in darkness Looking into fires and trees

Without motors

We hear all of nature's drones

Feel the slightest chirpings in our bones

Bring the outside world into our homes

Commemorating with rhyme and reason mime in season

The source of every sound

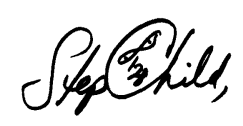

\section{Other Villages Other Voices}

Village voices in Nigeria

Muhammadu Marwa's people cry out

But are not heard here in Manhattan

Children in mass graves outside Kano

Small news arriving late in New York City

But Sunny Ade's smile is front page stuff

Yoruba minstrels bringing the original jive

The prototype shuffle, aboriginal cakewalks

Big winks and rolling eyes to the big city

Serene smiles blind to all corruption

Wicked cool ices memories of Biafra

Or any meditation on Nigerian crude sold cheap'

The Bonny crude, pure, clean, sulphur-free

Black gold, black futures sold to Seven Sisters

While Sunny smiles and takes his little steps

The hip bro wonders if "Bob may have been forwarded

So that Sunny could save the West with juju music."

According to some mysterious cosmic mastah plan

I like the man, I love the music, I put five

On the wet forehead of the talking drummer

(amplified to sound like Western cannon)

For playing nicely to the baby girl

So chubby and fine she should have been twins

But I am not fooled 